\title{
A persona da Tragédia em Nietzsche
}

Sergio Carvalho da Fonseca (IC)

\section{Resumo}

Por meio do conceito de Herói Trágico, presente na obra O Nascimento da Tragédia de Nietzsche, podemos detectar a antecipação de duas questões fundamentais acerca da persona do teatro contemporâneo, a saber, a crise do drama e o estabelecimento das tragédias como via de solução não só para a reflexão artística dessa arte, mas também como conteúdo para questionamento sobre a ética do homem pósmoderno.

Palavras Chave: Nietzsche, Tragédia, Teatro.

\section{Introdução}

A obra O Nascimento da Tragédia, de Nietzsche, além de tratar dos conceitos de drama e tragédia estudados na pesquisa anterior, traz também, através da perspectiva do Herói Trágico, uma interpretação acerca da persona contemporânea. Dela podemos concluir reflexões estéticas sobre a crise do drama moderno e das possibilidades e problemas da ética do homem atual.

\section{Resultados e Discussão}

Para entender essa persona numa maior amplitude tivemos inicialmente de tratá-la de forma mais aprofundada, a respeito da sua caracterização, nas obras de Nietzsche. Esse aprofundamento levou a duas questões que deveriam ser respondidas na busca de uma delimitação, e da forma mais completa possível, desse conceito de persona.

Começamos questionando o que levou Nietzsche a buscar, no estudo das tragédias, o problema do seu conteúdo. Isso nos fez pensar que havia um tipo de crise da persona do drama, que pudemos localizar inicialmente num ensaio de David Hume e com riqueza de detalhes numa obra contemporânea de um crítico literário, com fortes influências hegelianas, chamado Peter Szondi. Essa crise da persona surgiu devido a um descompasso na relação com seu público. $E$ isso só aconteceu, como detalharemos na pesquisa, quando houve uma revolução, detectada por Nietzsche através de sua análise estética, nos valores humanos. Para analisar esse problema, utilizamos a obra daquele que Nietzsche definiu como seu único percussor, Spinoza, e também dois filósofos que antecederam Nietzsche acerca do desencadeamento do pensamento estético, que o levaram ao entendimento dessa crise, Schopenhauer e Hegel.

Após tratar essa análise da crise do drama, surgiu a necessidade de atualização desse conceito de persona trágica. Ou seja, dentro da sociedade contemporânea encontrar o mesmo sentido que o Herói Trágico possuía inicialmente, agora vertido para o nosso mundo. Nisso as obras de Nietzsche, ao que parece devido aos seus questionamentos estéticos iniciais construídos em sua obra O Nascimento da Tragédia, são ricas na informação dos valores da persona contemporânea. No assentamento dos conceitos éticos nietzschianos dentro das tragédias, localizamos a admiração de Nietzsche por Shakespeare, por ter sido o dramaturgo que teve a capacidade de resgatar a tradição trágica. Na peça $A$ Falecida de Nelson Rodrigues, além de encontrarmos dentro da mesma peça exemplos de personagens de Sófocles e de Eurípedes, que nos remeteram ao início da nossa pesquisa, nos levaram a considerações acerca da tragédia e da sociedade contemporânea pela visão do dramaturgo Nelson Rodrigues que lança entendimento sobre a perspectiva não só estética do teatro, mas também filosófica de Nietzsche.

\section{Conclusões}

Mais do que uma obra que influencia a compreensão das artes através dos conceitos de Dionisíaco e Apolíneo, O Nascimento da Tragédia é uma obra que estimula o questionamento da arte teatral tanto do século $\mathrm{XX}$ como da nossa época.

\section{Agradecimentos}

Universidade Estadual de Campinas - UNICAMP Serviço de Apoio ao Estudante - SAE

\footnotetext{
NIETZSCHE, Friedrich Wilhelm. O Nascimento da Tragédia ou Helenismo e Pessimismo - Trad. J. Guinsburg - São Paulo, SP Companhia da Letras, 2007.

RODRIGUES, Nelson. Teatro completo de Nelson Rodrigues. Volume 3 - Rio de Janeiro - Nova Fronteira, 2004

SZONDI, Peter. Teoria do drama moderno (1880-1950) - Trad. Raquel Imanishi Rodrigues - São Paulo, SP - Cosac Naify, 2011.
} 